\title{
Faktor-Faktor Psikologis yang Mempengaruhi Postpartum Blues
}

\author{
Susanti Prasetya Ningrum \\ Universitas Muhammadiyah Malang, Jl. Bendungan Sutami No.188 Lowokwaru-Malang \\ e-mail : susanti_p@umm.ac.id
}

\begin{abstract}
Pregnancy and childbirth are the natural and normal processes experienced by every woman. In the process of pregnancy and childbirth every woman undergoes both physical and psychological changes so that women need to be prepared before entering this stage. Those who are not ready will be more likely to experience postpartum blues. This study aimed to determine the psychological factors that affect postpartum blues. The method was quantitative correlational with purposive sampling technique. Participating mothers were 6 months postpartum $(n=41)$. The research instruments were Edinburgh Postnatal Depression Scale (EPDS), coping stress scale, social support scale, and adjustment scale. The data was analyzed by simple linear regression. The result of this study showed that from the three independent variables giving predictions the biggest influence on the emergence of postpartum blues were adjustment variable (56,3\%), then coping stress (46,1\%), and social support (30,2\%).
\end{abstract}

Keywords: childbirth, postpartum blues, coping stress, adjustment, social support

\begin{abstract}
Abstrak
Kehamilan dan persalinan merupakan proses alamiah dan normal yang dialami oleh setiap wanita. Dalam proses kehamilan dan persalinan ini setiap wanita mengalami perubahanperubahan baik fisik maupun psikologis sehingga wanita perlu mempersiapkan diri sebelum memasuki tahapan ini, wanita yang kurang siap akan mengalami postpartum blues. Tujuan penelitian ini untuk mengetahui faktor-faktor psikologis yang memengaruhi postpartum blues. Jenis penelitian yaitu kuantitatif korelasional dengan teknik pengambila sampel purposive sampling. Responden penelitian yaitu ibu pasca melahirkan setelah 6 bulan $(\mathrm{n}=41)$. Instrumen penelitian yaitu Edinburgh Postnatal Depression Scale (EPDS), skala coping stress, skala dukungan sosial, dan skala penyesuaian diri. Analisa data menggunakan regresi linier sederhana dan menunjukkan bahwa dari ketiga variabel independen yang memberikan prediksi pengaruh terbesar pada munculnya postpartum blues adalah variabel penyesuaian diri $(56,3 \%)$, kemudian coping stress $(46,1 \%)$, dan dukungan sosial $(30,2 \%)$.
\end{abstract}

Kata Kunci: persalinan, postpartum blues, coping stress, penyesuaian diri, dukungan sosial

\section{Pendahuluan}

Setiap pasangan yang telah menikah pasti ada keinginan untuk mendapatkan anak. Anak di dalam suatu keluarga menjadi pelengkap dan perekat hubungan terutama antara suami istri, bahkan keluarga besar. Bagi seorang wanita sendiri mendapatkan anugerah anak dari kandungan sendiri sebagai bentuk kesempurnaan menjadi wanita yang sebutannya naik level menjadi "ibu". Untuk bisa disebut sebagai "ibu" harus melalui tahapan-tahapan panjang mulai dari kehamilan sampai persalinan.

Kehamilan, persalinan, dan sebutan sebagai "ibu" menjadi pengalaman penting bagi seorang wanita. Pengalaman yang didapatkan oleh wanita secara fisiologis, psikologis, maupun spiritualis baik yang dirasakan oleh calon ibu itu sendiri maupun keluarga. Pengalaman-pengalaman ini juga memiliki makna berbeda yang dirasakan oleh masing-masing calon ibu dan keluarganya. Artinya, pada sebagian calon ibu, kehamilan dan persalinan sebagai proses yang menyenangkan/ membahagia- 
kan dan berdampak positif dalam kehidupannya. Tetapi ada sebagian calon ibu yang mana kehamilan dan persalinan menjadi salah satu tahap transisi dalam kehidupan yang menegangkan. Apabila calon ibu berada di zona tidak nyaman maka respon yang muncul yaitu perasaanperasaan tidak nyaman sehingga berada pada kondisi krisis yang mengakibatkan stress pada diri ibu tersebut.

Menurut Mochtar (dalam Prawirohardjo, 2007) menyebutkan ada empat faktor utama yang berpengaruh terhadap proses persalinan pada wanita, yaitu faktor jalan lahir (passage), faktor janin (passanger), faktor tenaga atau kekuatan (power), dan faktor psikologis. Wanita yang hamil dan akan melahirkan perlu memiliki kondisi-kondisi psikologis yang stabil untuk membantunya dalam persalinan. Sebaliknya perasaan cemas, takut, tegang, dan khawatir akan menyebabkan stress pada ibu yang akan melahirkan sehingga proses persalinan tidak berjalan lancar.

Kondisi-kondisi psikologis seperti cemas dan stress ini bisa berlanjut pada ibu setelah melahirkan, yang mana kondisi ini sebagai bentuk pengembangan reaksireaksi ketakutan yang dirasakan sejak hamil sampai masa persalinan. Stress pasca melahirkan cenderung dialami oleh sebagian besar ibu yang baru pertama kali melahirkan. Kondisi stress ini menunjukkan bahwa sebagian ibu baru mengalami perubahan emosional yaitu terkadang merasa bahagia dan di waktu yang hampir bersamaan merasakan kesedihan tanpa sebab. Perubahan emosional ini ditandai oleh adanya kekhawatiran akan perhatian dari suami atau keluarga dekat yang teralihkan karena kehadiran bayi, ketakutan tubuhnya tidak lagi ideal, kekhawatiran tidak bisa memberikan ASI kepada buah hati, gelisah dan hilangnya minat untuk melakukan aktivitas sehari-hari yang sebelumnya disukai dan dilakukan, merasa terabaikan oleh suami dan keluarga dekat, merasa lelah dan kehilangan energi, kemampuan berpikir dan konsentrasi menurun, merasa bersalah dan tidak berguna, serta sulit tidur (Sylvia, 2006).

Keadaan psikologis yang berupa stress pada ibu melahirkan ini disebut dengan istilah baby blues syndrome yaitu perasaan sedih dan gelisah yang dialami oleh wanita setelah melahirkan dan lebih buruk sekitar hari ketiga atau keempat setelah persalinan. Akan tetapi, di dalam penelitian ini tidak menggunakan istilah baby blues syndrome karena penelitian ini melakukan pembatasan hanya pada gejala-gejala yang mengarah pada tingkat stress dan bukan gejala-gejala baby blues syndrome yang gejalanya cenderung ke arah postpartum depression.

Tingkat stress ibu pasca melahirkan dipengaruhi oleh dua faktor utama yaitu faktor internal dan eksternal. Faktor internal antara lain, fluktuasi hormonal, faktor psikologis dan kepribadian, adanya riwayat depresi sebelumnya, riwayat kehamilan dan persalinan dengan komplikasi, persalinan section caesarea, kesulitan menyusui, dan minimnya pengetahuan ibu akan perawatan bayi. Sedangkan faktor eksternal meliputi dukungan sosial, kondisi dan kualitas bayi, dan status mental suami (Henshaw, 2003). Hung dan Chung (dalam McQueen dan Mander, 2003) menyatakan bahwa faktor yang berkaitan dengan stress ibu pasca melahirkan adalah perubahan peran maternal, dukungan sosial, perubahan tubuh, kemampuan ibu mengatasi perasaanperasaan negatifnya, penyesuaian diri, dan harga diri.

Supartini (2004) menyatakan penyebab stress pada ibu pasca melahirkan ada dua yaitu faktor internal dan eksternal. Faktor internal meliputi adanya kondisi psikologis ibu yang diliputi oleh berbagai kekhawatiran, ketakutan, dan kecemasan akan dirinya sendiri dan buah hati, masalah keuangan, dan larangan atau mitos-mitos yang harus dipatuhi ibu pasca melahirkan. Sedangkan faktor eksternal meliputi tidak adanya dukungan dari lingkungan keluarga, adanya perubahan hormonal yang dirasakan oleh 
ibu, dan keluarga yang tidak harmonis (Supartini, 2004; Wikjhosastro, 2007).

Penelitian yang dilakukan oleh Pilliteri (2003) menghasilkan data bahwa kondisikondisi yang berpengaruh terhadap munculnya stress ibu pasca melahirkan yaitu ketergantungan ibu karena kelemahan fisik setelah melahirkan, rendahnya harga diri karena kelelahan, minim dukungan keluarga, dan ketegangan karena peran baru. Mengacu pada penjelasan di atas terkait dengan faktor-faktor yang memengaruhi tingkat stress pada ibu pasca melahirkan, dapat disimpulkan bahwa kematangan dan kesiapan ibu menjadi faktor utama supaya ibu tidak mengalami stress yang berlanjut pada baby blues syndrome. Ibu yang memiliki kematangan dan kesiapan akan berhasil mengatasi stress setelah persalinan, sebaliknya ibu yang kurang pengetahuan akan persalinan dan kurang memiliki kesiapan tidak mampu mengatasi stress. Pada saat itulah sangat diperlukan penerapan coping yang efektif. Ibu yang mengalami stress cenderung mengalami kesulitan dalam penyesuaian diri karena dalam dirinya sedang mengalami ketidakseimbangan sehingga untuk menyeimbangkan dan menyesuikan diri diperlukan perilaku coping.

Penelitian yang dilakukan oleh Thurgood, Avery, dan Williamson (2009) di Kanada, Jerman, Belanda, dan Irlandia dengan subjek wanita rentang usia 32-45 tahun menunjukkan bahwa sekitar $75 \%$ mengalami stress pasca melahirkan. Tanda stress pasca melahirkan pada subjek ini yaitu perasaan sedih, kecewa, marah pada diri sendiri, cemas, ketakutan berlebihan tidak bisa menyusui, ketakutan akan kehilangan pekerjaan, dan sebagainya. Hasil penelitian ini juga menyebutkan ibuibu yang mengalami stress pasca melahirkan berlanjut sampai minggu ke-4 bahkan minggu ke-12 karena pemakaian coping yang kurang efektif. Selain itu, sekitar 45\% menyatakan bahwa kehamilannya tidak direncanakan dan tidak ada persiapan kehamilan dengan baik.
Faktor internal lain yang juga memberi sumbangan bagi stress ibu pasca melahirkan yaitu penyesuaian diri. Sebenarnya penyesuaian diri ini dimulai saat ibu mengetahui pertama kali jika dirinya sedang hamil. Ibu akan mengalami perubahan baik fisik dan psikologis sehingga perlu penyesuaian dan adaptasi pada setiap perubahan yang terjadi terutama untuk kehamilan pertama. Ibu yang sulit beradaptasi dengan kehamilannya menjadi stressor sendiri sehingga ibu kurang tenang dan rileks. Jika ibu tidak segera bisa melakukan penyesuaian diri, maka hal ini bisa memunculkan tingkat stress yang berlanjut sampai ibu melahirkan. Penelitian yang telah dilakukan oleh Nichols, Roux, dan Harris (2007) di USA pada 100 wanita yang sedang hamil menunjukkan bahwa wanita yang memiliki pengetahuan akan perubahan fisik dan psikologis selama hamil mampu menyesuaikan diri. Sebaliknya wanita yang kurang pemahaman akan perubahan yang terjadi saat hamil akan merasa sedih dan kecewa dengan kehamilannya dan tidak dapat menyesuaikan diri dengan kehamilannya. Penelitian ini juga mengungkapkan bahwa wanita hamil yang mampu menyesuaikan diri adalah wanita yang mendapatkan dukungan sosial dari pasangan dan keluarga dekat.

Dukungan sosial dari keluarga sangat membantu ibu hamil berada pada emosi yang stabil sehingga tidak stress. Tidak semua ibu hamil berada pada situasi ideal dan mendapatkan dukungan dari suami maupun keluarganya. Permasalahanpermasalahan sosial seperti konflik dengan keluarga atau suami, kondisi ekonomi yang kurang, minimnya informasi yang didapatkan bisa memberikan tekanan tersendiri. Selain itu orang-orang di sekitar ibu hamil yang memberikan larangan-larangan berupa mitos-mitos tertentu juga menjadikan ibu baru ini menjadi tidak nyaman sehingga merasa sebagai sasaran dari mitos-mitos itu dan merasakan sendiri. Apalagi jika ibu baru ini tidak mendapatkan dukungan dari 
pasangan, maka sangat mudah untuk berada pada tingkat stress tinggi.

Berdasarkan uraian di atas, maka peneliti tertarik untuk melakukan penelitian terkait dengan tingkat stress pada ibu pasca melahirkan sekaligus faktor-faktor yang memengaruhinya. Manfaat penelitian ini secara teoretis dapat menambah kajian bagi Psikologi Klinis serta nantinya dapat digunakan sebagai salah satu pengetahuan guna merancang intervensi yang tepat. Secara umum manfaat penelitian ini adalah menambah pengetahuan ibu yang sedang hamil akan kondisi-kondisi terkait stress pasca melahirkan sehingga ibu telah mempersiapkan diri untuk menghadapi stressor.

\section{Postpartum Blues}

Periode postpartum terjadi sesaat setelah bayi dilahirkan sampai organ-organ ibu kembali normal seperti sebelum melahirkan yang biasanya juga sering disebut masa nifas (Bobak, Lowdermilk dan Jensen, 2005). Pada masa postpartum ini terjadi pula perubahan-perubahan psikologis sebagai akibat perubahan fisik yang terjadi dan hal ini normal terjadi. Apabila ibu dapat memahami dan menyesuaikan diri dengan beberapa perubahan baik fisik maupun psikologis, maka ibu tidak mengalami ketakutan, kekhawatiran atau kecemasan. Sebaliknya ketika ibu baru ini terlalu takut, khawatir, dan cemas dengan perubahan yang terjadi dalam dirinya maka ibu bisa mengalami ganguan-gangguan psikologis. Terdapat tiga jenis gangguan psikologis terkait dengan afek atau mood ibu pasca melahirkan yaitu postpartum blues, depresi postpartum, dan psikosis postpartum (Henshaw, 2003).

Postpartum blues yaitu suatu keadaan depresi ringan yang sifatnya sementara, dialami sebagian besar ibu yang terjadi sebagai akibat perubahan-perubahan baik fisiologis, hormonal, maupun psikologis (Pieter dan Lubis, 2010). Gangguan ini terjadi 14 hari pertama pasca melahirkan dan terjadi puncak reaksi gangguan pada 3 atau 4 hari pasca melahirkan. Postpartum blues ini sering terjadi pada hampir setiap wanita pasca melahirkan. Periode postpartum menjadi satu hal yang penting untuk digunakan sebagai tanda paling awal apakah ibu mengalami postpartum baby blues atau tidak.

Ibu pasca melahirkan di Indonesia hampir sebagian besar yang tidak menyadari bahwa mereka mengalami postpartum blues dan masyarakat sendiri masih menganggap bahwa gejala-gejala yang muncul pada ibu baru itu merupakan sesuatu yang wajar. Masyarakat menganggap bahwa apa yang dirasakan oleh ibu baru merupakan naluri seorang ibu karena baru memiliki bayi dan rasa ingin selalu di dekat bayinya. Selain itu belum ada survey resmi dari pemerintah terkait dengan postpartum blues pada ibu pasca melahirkan.

Gejala postpartum blues mengarah pada keadaan yang sulit untuk dijelaskan, ada perasaan sedih, mudah tersinggung, kelelahan, dan susah tidur. Seringkali ibu yang mengalami postpartum blues berkembang lebih lama dan lebih berat intensitasnya. Menurut American Psychiatric Association (2013), gejala postpartum blues terlihat secara psikologis antara lain a) perasaan cemas, khawatir berlebihan, sedih, murung, dan sering menangis tanpa sebab yang jelas; b) seringkali merasa kelelahan dan sakit kepala/ migren; c) perasaan tidak mampu, misalnya mengurus si kecil; dan d) adanya perasaan putus asa.

\section{Faktor-faktor yang Memengaruhi Post- partum Blues}

Coping stress. Persalinan atau melahirkan merupakan peristiwa penting dalam kehidupan wanita. Hal ini menjadi peristiwa yang menyenang-kan karena telah berakhir masa kehamilan dan ibu akan memberikan yang terbaik bagi anaknya. Akan tetapi tidak jarang pula ditemui, menjelang persalinan calon ibu merasakan ketegangan dan ketakutan yang luar biasa. Ini berpengaruh terhadap kondisi psikologis 
ibu pasca melahirkan karena beberapa wanita mengalami perubahan emosional. Seperti sudah dijelaskan sebe-lumnya, peristiwa ini adalah wajar tetapi akan berdampak buruk bagi ibu, bayi dan keluarga jika dibiarkan berlarut-larut.

Seorang ibu membutuhkan kesiapan yang matang untuk mengantisipasi ciri-ciri dari munculnya kondisi tegang yang bisa berakibat pada tingkat stress. Kemampuan ibu untuk mengatasi stressor ini disebut dengan coping stress. Istilah coping menurut Sunberg, Winebager, dan Taplin (2007) biasa dikaitkan dengan mekanisme pertahanan diri baik yang bersifat positif maupun negatif.

Folkman dan Lazarus (dalam Sarafino, 1994) membedakan bentuk dan fungsi coping ke dalam dua jenis yaitu 1) problem focused coping (PFC) merupakan bentuk coping yang lebih diarahkan kepada upaya untuk mengurangi tuntutan dari situasi yang penuh tekanan, artinya coping yang muncul terfokus pada masalah individu yang akan mengatasi stress dengan mempelajari cara-cara keterampilan yang baru. Individu cenderung menggunakan strategi ini ketika mereka percaya bahwa tuntutan dari situasi dapat diubah. 2) emotion focused coping (EFC) merupakan bentuk coping yang diarahkan untuk mengatur respon emosional terhadap situasi yang menekan. Individu dapat mengatur respon emosionalnya dengan pendekatan behavioral dan kognitif.

Penyesuaian Diri. Wanita yang hamil dan melahirkan merupakan ciri dari tugas perkembangan pada masa dewasa muda seperti yang dikemukakan oleh Havighurst (dalam Hurlock, 1980) diantaranya mulai membina keluarga, mengasuh anak, dan mengelola rumah tangga. Berkaitan dengan tugas-tugas perkembangan itu, wanita melakukan penyesuaian-penyesuaian sesuai dengan peran baru melalui proses kehamilan dan persalinan yaitu peran menjadi ibu dan orang tua. Untuk bisa menjadi ibu dan orang tua yang sesuai harapan, tentu saja diawali dengan penyesuaian ibu tersebut terhadap beberapa kondisi yang mengalami perubahan pasca melahirkan.

Kehamilan dan persalinan seperti diuraikan di atas adalah peristiwa alamiah dan normal, tetapi pada sebagian wanita kedua peristiwa itu bisa menjadi periode krisis dalam kehidupan wanita. Hal ini disebabkan pada setiap tahap kehamilan dan sampai pada persalinan ibu akan mengalami perubahan fisik maupun psikologis sehingga perlu melakukan penyesuaian diri dengan kondisi tersebut. Definisi penyesuaian diri dapat ditinjau dari tiga sudut pandang yaitu penyesuaian diri sebagai bentuk adaptasi (adaptation), penyesuaian diri sebagai bentuk konformitas (conformity), dan penyesuaian diri sebagai usaha penguasaan (mastery) (Schneiders, 1955). Penyesuaian diri adalah suatu proses yang mencakup respon-respon mental dan tingkah laku, yang merupakan usaha individu supaya berhasil menghadapi kebutuhan internal, ketegangan, frustrasi, konflik-konflik serta menghasilkan kualitas keselarasan antara tuntutan dari dalam diri individu dengan tuntutan dunia luar atau lingkungan tempat individu berada.

Menurut Schneiders (1955) penyesuaian diri seseorang dapat dilihat dari aspekaspeknya yaitu 1) penyesuaian pribadi adalah penerimaan individu terhadap dirinya sendiri. Penyesuaian pribadi berkaitan dengan konflik, tekanan, dan keadaan dalam diri individu baik fisik maupun psikisnya. Individu yang mengalami hambatan dalam penyesuaian pribadi ditandai oleh adanya kecemasan, perasaan bersalah, perasaan tidak puas akan dirinya sendiri, 2) penyesuaian sosial yang terjadi dalam lingkup hubungan sosial dimana individu tinggal dan berinteraksi.

Sama halnya dengan yang terjadi pada wanita yang hamil dan melahirkan/ bersalin. Kehamilan dan persalinan adalah proses transisi dan identitas sebagai wanita. Wanita perlu menyesuaikan diri dengan perubahan-perubahan dalam diri saat hamil dan bersalin. Secara lebih jelas, Pieter dan 
Lubis (2010) membagi fase penyesuaian diri wanita pasca melahirkan sebagai berikut: 1) fase take in yaitu fase dimana ibu sangat tergantung pada diri sendiri yang mana ibu menceritakan pengalaman melahirkan secara berulang-ulang kepada setiap orang baik orang di sekitarnya maupun orang asing yang berkunjung ke rumah, 2) fase taking hold yaitu fase peralihan yang awalnya ketergantungan menjadi kemandirian dan berkisar selama 3-10 hari. Fase ini menentukan ibu bisa melalui penyesuaian dengan baik atau tidak. Ketika ibu tidak dapat melalui fase ini maka bisa menyebabkan stress bahkan depresi postpartum, 3) fase letting go yaitu fase menerima tanggung jawab dengan peran barunya yang berlangsung selama 10 hari setelah melahirkan, dan 4) fase bounding attachment yaitu fase kelekatan antara ibu dengan anak. Fase ketiga dan keempat mustahil tercapai ketika ibu kesulitan menyesuaikan diri dengan perubahan pasca melahirkan.

Dukungan Sosial. Wanita yang telah mengalami proses persalinan, pada periode ini membutuhkan bantuan. Dukungan sosial penting untuk kesehatan ibu, baik fisik maupun psikologis setelah ibu melahirkan terutama saat ibu memiliki peran baru sebagai ibu (Hung, 2004). Pierce (dalam Kail dan Cavanaug, 2000) mendefinisikan dukungan sosial sebagai sumber emosional, informasional atau pendampingan dari orang-orang di sekitar individu yang sedang menghadapi masalah dan dalam kondisi krisis. Definisi ini hampir sama dengan yang disampaikan oleh Saroson (dalam Smet, 1994) bahwa dukungan sosial adalah interaksi interpersonal yang bertujuan untuk memberikan bantuan kepada seseorang sehingga yang bersangkutan merasakan adanya bentuk perhatian, bernilai, dan dicintai.

Berdasarkan pendapat dua ahli di atas dapat disimpulkan bahwa dukungan sosial adalah dukungan atau bantuan yang diberikan oleh orang terdekat terhadap seseorang yang sedang menghadapi permasalahan sehingga merasakan adanya bentuk perhatian, dihargai dan menjadi bagian dari kelompok.

Dukungan sosial ini memiliki klasifikasi di dalamnya, seperti disampaikan oleh Cohen dan Syme (1985), yaitu; (1) Dukungan informasi, yaitu memberi-kan penjelasan tentang situasi dan segala sesuatu yang berhubungan dengan masalah yang sedang dihadapi individu. Dukungan ini meliputi mem-berikan nasehat, petunjuk, masukan atau penjelasan bagaimana seseorang bersikap. (2) Dukungan emosional, yang meliputi ekspresi empati misalnya mendengar-kan, bersikap terbuka, menunjukkan sikap percaya terhadap apa yang dikeluhkan, mau memahami, ekspresi kasih sayang dan perhatian. Dukungan emosional akan membuat penerimanya merasa berharga, nyaman, aman, terja-min, dan disayangi. (3) Dukungan instrumental adalah bantuan yang diberikan secara langsung, bersifat fasilitas atau materi misalnya menyediakan fasilitas yang diperlukan, meminjamkan uang, memberikan ma-kanan, permainan atau bantuan yang lain. (4) Dukungan appraisal atau penilaian, dukungan ini bisa berbentuk penilaian yang positif, penguatan (pembenaran) untuk melakukan sesuatu, umpan balik atau menunjukkan perbandingan sosial yang membuka wawasan seseorang yang sedang dalam keadaan stress.

Dukungan sosial yang dibutuhkan oleh ibu pasca melahirkan tidak hanya dari suami, tetapi juga dari keluarga dan lingkungan sekitarnya. Karena kenyataanya orang lain yang berada di sekitar ibu ini yang juga memiliki peran sebagai stressor. Misalnya saja pemberian nasehat yang cenderung melarang ibu untuk tidak melakukan ini dan itu menjadi sumber stressor tersendiri. Padahal ibu belum tentu minim pengetahuan terkait perawatan setelah melahirkan maupun perawatan bayi sehingga daripada memberikan nasehat atau informasi yang banyak lebih baik 
langsung memberikan dukungan dalam bentuk bantuan langsung.

\section{Metode Penelitian}

\section{Rancangan Penelitian}

Penelitian ini menggunakan pendekatan penelitian kuantitatif yaitu rancangan penelitian yang digunakan untuk mengetahui hubungan komparatif sejumlah subjek melalui satu pengambilan data yaitu skala.

\section{Subjek Penelitian}

Populasi penelitian ini adalah ibu pasca melahirkan/ bersalin di RSIA X dan RSIA Y di Malang, serta RSIA Z di Blitar. Rujukan tempat penelitian didasarkan pada adanya kasus postpartum blues di ketiga rumah sakit tersebut, yang mana di klinik psikologi ketiga rumah sakit tersebut menangani 2-5 kasus perbulan. Teknik pengambilan sampel menggunakan purposive sampling, yaitu pengambilan sampel berdasarkan kriteria spesifik yang telah ditetapkan. Adapun kriteria spesifik subjek penelitian adalah 1) ibu yang memiliki bayi usia 4-7 hari, 2) kehamilan ibu adalah kehamilan yang pertama, dan 3) berusia 2040 tahun. Jumlah subjek penelitian sebanyak 41 orang yang tersebar dari 3 RSIA yaitu 8 orang dari RSIA X, 18 orang dari RSIA Y, dan 15 orang dari RSIA Z.

\section{Variabel dan Instrumen}

Penelitian ini mengkaji empat variabel, variabel terikat adalah postpartum blues dan variabel bebas yaitu coping stress, penyesuaian diri, dan dukungan sosial.

Tingkat stress pasca melahirkan adalah kondisi afek negatif ringan yang dialami oleh ibu setelah melahirkan, ditandai dengan beberapa gejala seperti kesedihan, kecemasan, ketakutan, dan kekhawatiran berlebihan. Coping stress adalah kemampuan ibu dalam menghadapi situasi atau peristiwa yang membuatnya merasa mengalami tekanan psikologis. Penyesuaian diri adalah kemampuan ibu untuk melakukan adaptasi dengan peru- bahan fisik maupun emosional setelah melahirkan.

Metode pengumpulan data dengan menggunakan skala Likert yang disusun berdasarkan teori-teori dari variabel penelitian. Skala coping stress disusun berdasarkan teori Folkman dan Lazarus (dalam Sarafino, 1994) membedakan bentuk dan fungsi coping ke dalam dua jenis yaitu 1) problem focused coping $(P F C)$ dan 2) emotional focused coping $(E F C)$. Skala penyesuaian diri disusun berdasarkan teori Schneiders yaitu penyesuaian pribadi dan penyesuaian sosial. Berikutnya untuk skala dukungan sosial disusun dari jenis dukungan sosial yang disampaikan Cohen dan Syme (1985) yaitu dukungan informasi, dukungan emosional, dukungan instrumental, dan dukungan appraisal atau penilaian. Sedangkan untuk postpartum blues disusun berdasarkan gejala-gejala postpartum blues yang disampaikan oleh American Psychiatric Association (2013) bahwa gejala postpartum blues terlihat secara psikologis antara lain a) perasaan cemas, khawatir berlebihan, sedih, murung, dan sering menangis tanpa sebab yang jelas, b) seringkali merasa kelelahan dan sakit kepala/ migren, c) perasaan tidak mampu, misalnya mengurus si kecil, dan d) adanya perasaan putus asa.

Sedangkan untuk postpartum blues menggunakan instrumen Edinburgh Postnatal Depression Scale (EPDS) yaitu kuesioner yang dapat mengukur intensitas perubahan perasaan depresi selama 7 hari pasca persalinan. Kuesioner ini terdiri dari 10 item, dimana setiap item memiliki 4 pilihan jawaban yang skornya bergerak dari 0-3. Skala ini harus dijawab sendiri oleh ibu pasca melahirkan dan dapat diselesaikan rata-rata dalam waktu 5 menit. EPDS telah teruji validitasnya di beberapa negara seperti Belanda, Swedia, Australia, Italia dan Indonesia. Di Indonesia telah teruji validitasnya dan telah dipublikasikan dengan membandingkan skor instrumen tersebut dengan DSM-IV. Nilai skoring 
lebih besar dari 12 memiliki sensitivitas $86 \%$ dan nilai prediksi positif $73 \%$ untuk mendiagnosis kejadian postpartum blues (Cox, Holden dan Sagovsky, 1987).

Instrumen penelitian kemudian diujicobakan kepada subjek sebanyak 25 orang. Subjek try out instrumen berasal dari dua RSIA di Malang yang menunjukkan adanya indikasi postpartum blues. Dari 25 subjek try out ini hanya 8 orang yang menunjukkan postpartum blues, sedangkan 17 orang lainnya hanya mengindikasikan postpartum blues yang bisa dilihat dari beberapa ciri postpartum blues yang ada pada ke-17 subjek. Selanjutnya hasil uji coba dilakukan uji validitas dan reliabilitas seperti pada tabel 1 .

\section{Prosedur Penelitian}

Penelitian ini terdiri dari tiga tahapan yaitu tahap persiapan, pelaksanaan penelitian, dan analisa data. Tahap persiapan diawali dengan melakukan asessment awal kepada beberapa ibu yang telah melahirkan untuk mendapatkan gambaran mengenai stress pasca melahirkan. Selanjutnya menentukan jumlah subjek penelitian dengan menetapkan karakteristik-karakteristiknya. Langkah berikutnya menyusun instrumen penelitian yaitu skala bentuk Likert. Tahap pelaksanaan dilakukan dengan penyebaran skala kepada subjek penelitian. Tahap terakhir yaitu analisa data menggunakan analisis regresi linier sederhana dengan software statistik.

\section{Hasil Penelitian dan Pembahasan}

\section{Hasil Penelitian}

Hasil Uji Asumsi Dasar. Hasil dari penyebaran instrumen dila-kukan analisa data dengan menggunakan analisis regresi linier sederhana. Sebelum melakukan analisa regresi linier sederhana, dilakukan uji asumsi dasar sebagai prasyarat. Hasil uji asumsi dasar ada dua yaitu uji normalitas dan linieritas, dimana hasilnya dapat dilihat pada tabel 2.

Tabel 2 menunjukkan hasil uji normalitas dimana untuk variabel coping

Tabel 1

Hasil Uji Validitas dan Uji Reliabilitas

\begin{tabular}{lccccc}
\hline \multicolumn{1}{c}{ Instrumen } & Jumlah Item & Item Valid & Item Gugur & Nilai Validitas & Nilai Reliabilitas \\
\hline Skala coping stress & 27 & 22 & 5 & $-0.229-0.800$ & 0.762 \\
Skala penyesuaian diri & 36 & 29 & 7 & $-0.072-0.757$ & 0.757 \\
Skala dukungan sosial & 32 & 29 & 3 & $0.209-0.811$ & 0.755 \\
\hline
\end{tabular}

Tabel 2

Hasil Uji Normalitas

One-Sample Kolmogorov-Smirnov Test

\begin{tabular}{|c|c|c|c|c|c|}
\hline & & $\begin{array}{c}\text { Dukungan } \\
\text { Sosial }\end{array}$ & $\begin{array}{l}\text { Coping } \\
\text { Stress }\end{array}$ & $\begin{array}{c}\text { Penyesuaian } \\
\text { Diri }\end{array}$ & $\begin{array}{l}\text { Postpartum } \\
\text { Blues }\end{array}$ \\
\hline $\mathrm{N}$ & & 41 & 41 & 41 & 41 \\
\hline \multirow[t]{2}{*}{ Normal Parameters ${ }^{\mathrm{a}, \mathrm{b}}$} & Mean & 68.1951 & 64.1707 & 68.1707 & 24.3415 \\
\hline & Std. Deviation & 13.57796 & 17.68460 & 16.29402 & 4.59679 \\
\hline \multirow[t]{3}{*}{ Most Extreme Differences } & Absolute & .184 & .181 & .173 & .202 \\
\hline & Positive & .184 & .181 & .173 & .155 \\
\hline & Negative & -.090 & -.095 & -.146 & -.202 \\
\hline Kolmogorov-Smirnov Z & & 1.176 & 1.158 & 1.106 & 1.292 \\
\hline Asymp. Sig. (2-tailed) & & .126 & .137 & .173 & .071 \\
\hline
\end{tabular}

a. Test distribution is Normal. 
stress nilai signifikansi yang diperoleh sebesar 0.137 ( $p>0.05)$, maka distribusi data tersebut normal. Variabel penyesuaian diri dengan nilai signifikansi 0.173 ( $>0.05$ ), maka distribusi data normal, variabel dukungan sosial dengan nilai signifikansi 0.126 ( $\mathrm{p}>0.05)$ dapat disimpulkan distribusi data normal, dan variabel postpartum blues dengan nilai signifikansi 0.071 ( $\mathrm{p}>0.05$ ) disimpulkan data berdistribusi normal. Dari hasil uji normalitas tersebut dapat disimpulkan bahwa semua data dari keempat variabel berdistribusi normal.

Setelah dilakukan uji normalitas, maka tahap berikutnya adalah uji linieritas antara variabel dependen (Y) dengan variabel independen (X). Hasil uji linieritas dapat dilihat pada tabel 3 .

Hasil uji linieritas diketahui bahwa semua variabel independen (X) berhubungan linier dengan variabel dependen (Y). Keseluruhan variabel memperlihatkan bahwa nilai sig. deviation from linearity lebih besar dari 0.05 , dapat disimpulkan bahwa uji asumsi klasik linieritas semua variabel terpenuhi.

Setelah dua uji asumsi dasar yaitu uji normalitas dan uji linieritas terpenuhi, maka uji regresi linier sederhana dapat dilakukan.

Hasil Uji Regresi Linier Sederhana. Tahap uji analisa data berikutnya adalah analisa data dengan menggunakan analisis regresi linier sederhana antara variabel independen $(\mathrm{X})$ dengan variabel dependen (Y).

Hasil uji linier sederhana pada tabel 4 memperlihatkan bahwa, pertama, ada korelasi antara variabel coping stress dengan postpartum blues $\quad(\mathrm{R}=0.679$; $\mathrm{p}<0.05)$. Kedua, ada korelasi antara penyesuaian diri dengan postpartum blues $(\mathrm{R}=0.750 ; \mathrm{p}<0.05)$. Ketiga, ada korelasi antara dukungan sosial dengan postpartum blues $(\mathrm{R}=0.549 ; \mathrm{p}<0.05)$. Hasil uji regresi linier sederhana pada tabel 4 menunjukkan bahwa nilai signifikansi ketiga variabel independen $(\mathrm{X})$ terhadap variabel dependen (Y) yaitu postpartum blues sebesar 0.00 $(\mathrm{p}<0.05)$ yang dapat disimpulkan bahwa ketiga variabel independen memiliki hubungan terhadap variabel postpartum blues.

Berikutnya dari ketiga variabel independen yang memberikan prediksi pengaruh terbesar pada munculnya postpartum blues adalah variabel penyesuaian diri (56.3\%), kemudian coping stress (46.1\%), dan dukungan sosial (30.2\%).

Selain bisa mengetahui hubungan dan pengaruh variabel independen $(\mathrm{X})$ dengan variabel dependen (Y), analisa regresi sederhana juga bisa mengetahui arah hubungan diantara variabel tersebut. Hasil analisa regresi sederhana menunjukkan jika arah hubungan ketiga variabel independen tersebut negatif. Hasil ini memberikan gambaran bahwa semakin ibu pasca

Tabel 3

Hasil Uji Linieritas

\begin{tabular}{|c|c|c|c|}
\hline Variabel X & Variabel Y & $\begin{array}{l}\text { Nilai Sig.Deviation } \\
\text { from Linearity }\end{array}$ & Keterangan \\
\hline Coping stress & Postpartum Blues & $0.031(\mathrm{p}>0.05)$ & Hubungan Linier \\
\hline Penyesuaian Diri & Postpartum Blues & $0.290(\mathrm{p}>0.05)$ & Hubungan Linier \\
\hline Dukungan Sosial & Postpartum Blues & $0.588(\mathrm{p}>0.05)$ & Hubungan Linier \\
\hline
\end{tabular}

Tabel 4

Hasil Uji Regresi Linier Sederhana

\begin{tabular}{lcccc}
\hline \multicolumn{1}{c}{ Variabel } & $\mathrm{R}$ & $\mathrm{R}^{2}$ & $\mathrm{~F}$ & Signifikansi \\
\hline Coping stress - postpartum blues & 0.679 & 0.461 & 33.333 & $0.00(\mathrm{p}<0.05)$ \\
Penyesuaian diri - postpartum blues & 0.750 & 0.563 & 50.284 & $0.00(\mathrm{p}<0.05)$ \\
Dukungan sosial - postpartum blues & 0.549 & 0.302 & 16.865 & $0.00(\mathrm{p}<0.05)$ \\
\hline
\end{tabular}


melahirkan memiliki penyesuaian diri yang baik, maka postpartum blues akan turun. Berikutnya ketika ibu memiliki coping stress yang positif, maka postpartum blues juga akan turun. Kesimpulan terakhir yaitu ketika ibu pasca melahirkan mendapatkan dukungan sosial yang positif, maka postpartum blues akan turun juga.

\section{Pembahasan}

Hasil penelitian menunjukkan bahwa ketiga variabel independen $(\mathrm{X})$ yaitu coping stress, penyesuaian diri, dan dukungan sosial ternyata memiliki pengaruh terhadap postpartum blues. Pengaruh variabel yang paling besar untuk memprediksi terjadinya postpartum blues yaitu penyesuaian diri $(\mathrm{R}=0.750 ; \mathrm{p}<0.05)$. Pada ibu yang baru mengalami kehamilan pertama tentu saja perlu menyesuaikan diri dengan beberapa perubahan yang terjadi diantara hamil dan bersalin. Perubahan yang terjadi termasuk dalam menjalankan aktivitas dan peran barunya sebagai ibu pada minggu-minggu pertama atau bahkan bulan-bulan pertama. Pada sebagian ibu yang mengalami kesulitan untuk menyesuaikan diri dengan aktivitas dan peran barunya, akan mengembangkan perasaanperasaan tidak nyaman seperti perasaan takut, khawatir, sedih, dan merasa sendirian. Apalagi jika lingkungan sekitar tidak memberikan perhatian kepada ibu dan perhatian orang-orang di sekitarnya lebih mengarah kepada bayinya (Pfuhlmann, Stoeber dan Beckmann, 2002). Perasaanperasaan yang dirasakan oleh ibu pasca melahirkan ini jika tidak segera ditangani akan semakin lama periodenya dan intensitas perasaan tidak nyaman menjadi semakin sering. Perasaan-perasaan tidak nyaman ini menjadi tanda awal munculnya gejala-gejala postpartum blues (Nes, Hauge, Landolt, Eskedal, Roysamb, Kornstad, Irgens dan Kristensen, 2014).

Kehamilan dan persalinan adalah suatu proses alamiah yang dialami oleh setiap wanita yang mana dalam prosesnya sangat dipengaruhi oleh reaksi-reaksi psikologis.
Reaksi terhadap kehamilan dan persalinan yang dialami oleh setiap wanita hamil berbeda-beda dan reaksinya pun berbeda pula, ada yang khawatir, takut, cemas, atau bahkan bahagia. Sedangkan yang berpengaruh terhadap munculnya beragam reaksi psikologis ini bermacam-macam mulai dari diri ibu hamil itu, suami, rumah tangga dan lingkungan sekitarnya. Reaksi psikologis ini akan memengaruhi sikap, perilaku, dan tingkat emosional ibu. Saat ibu kurang bisa melakukan kontrol yang efektif terhadap reaksi psikologis ini, maka terjadi tekanan psikologis yang disebut dengan stress.

Stress pada ibu pasca persalinan ini sering terjadi hampir pada semua ibu yang telah mengalami persalinan. Stress pasca melahirkan terjadi pada hari pertama sampai hari ke-10 setelah persalinan yang ditandai dengan perasaan kesepian, cemas, bingung, gelisah, letih, pelupa, dan tidak dapat tidur (Pilliteri, 2003). Tanda-tanda stress pasca melahirkan menjadi tanda awal postpartum blues. Ketika ibu kurang memiliki keterampilan dalam menghadapi stressor yang disebut dengan coping. Bentuk coping ada dua yaitu problem focused coping dan emotional focused coping. Hasil penelitian memperlihatkan bahwa pada ibu yang mengalami postpartum blues sebagian menggunakan problem focused coping $($ mean $=64.1707)$ dibandingkan emotional focused coping (mean= 24.3415) .

Sarafino (1994) membedakan kedua bentuk coping ini dari cara individu dalam menghadapi stressor. Problem focused coping (PFC) merupakan bentuk coping yang bertujuan mengurangi tuntutan dari situasi yang penuh tekanan dengan belajar keterampilan yang baru. Ibu yang menggunakan coping ini memiliki keyakinan bahwa tuntutan situasi yang penuh tekanan itu bisa berubah. Penelitian ini juga memberikan data jenis PFC yang sering digunakan oleh ibu pasca melahirkan yaitu information seeking $($ mean $=0.7073)$, yang bisa ditunjukkan dari ibu membutuhkan pendapat dan pandangan orang terdekat 
saat sedang menghadapi persoalan. Persoalan yang berkaitan dengan mengasuh bayi, strategi berbagi dalam mengasuh bayi yang mana jam tidur bayi belum teratur, dan sebagainya. Kemudian jenis berikutnya yaitu assistance seeking (mean $=8.5122$ ) yaitu ibu mencari dukungan dan membutuhkan bantuan orang terdekat. Istri yang baru melahirkan terkadang telah memiliki strategi dalam menjalankan peran sebagai ibu dan saat mengasuh anak, tetapi terkadang strategi itu kurang bisa dijalankan karena kurangnya dukungan dari lingkungan terdekat, terutama suami. Jenis ketiga yang digunakan oleh ibu yaitu direct action (mean $=8.2683$ ) yaitu melakukan penghindaran pada orang-orang yang akan membantunya. Ada ibu yang sangat khawatir kepada bayinya, maka ia tidak memperbolehkan orang lain untuk memegang, ada juga ibu baru ini yang menghindari bayinya karena merasa belum siap dengan peran barunya. Direct action ini juga bisa dalam bentuk sebenarnya ibu telah mempersiapkan peran barunya, tetapi karena kurang adanya dukungan dari keluarga, terutama suami maka persiapan yang dimiliki oleh ibu ini tidak bisa dimunculkan. Selanjutnya yaitu planfull problem solving (mean= 8.2439). Ibu baru memiliki langkah-langkah untuk menyelesaikan masalahnya terkait dengan peran baru sebagai ibu. Misalnya ketika ibu memiliki perasaan lelah ketika harus sering terbangun di malam hari dan jam tidurnya berkurang, ibu mampu menimbang hal apa saja yang bisa membantunya untuk meringankan kelelahan itu dengan mengurangi aktivitas yang tidak berkaitan dengan mengurus bayi atau ibu bisa berbicara langsung pada orang sekitarnya untuk membantu meringankan beban ketika harus mengurus bayi.

Sedangkan emotional focused coping (EFC) mengarah pada individu berusaha untuk mengatur respon emosional dari situasi yang penuh tekanan. Jenis EFC ini yang paling banyak digunakan oleh ibu yaitu denial $($ mean $=8.4878)$, dimana ketika ada masalah ibu cenderung untuk meng- anggap tidak ada masalah. Kemudian avoidance yaitu ibu menghindari masalah dengan berkhayal seandainya berada pada situasi yang menyenangkan, tidak mengalami perubahan yang drastis dari hamil dan bersalin, tidak mendapatkan kesulitan saat merawat bayi, dan sebagainya. Jenis ketiga dan keempat yaitu self-criticism (mean $=7.9512)$ dan positive reappraisal $($ mean $=5.4634)$. Ketika istri pasca melahirkan lebih sering menggunakan PFC maka ini akan mendorong keefektifan dalam menghadapi stressor maka ia mampu menyesuaikan diri dengan baik. Sebaliknya ketika EFC lebih dominan sehingga muncul gejala-gejala seperti khawatir, cemas, tidak berdaya, sedih, dan gejala negatif lainnya maka ia dikatakan gagal dalam menyesuaikan diri dan bisa mengarah pada postpartum blues. Memang EFC tidak selalu menghasilkan efek negatif, akan tetapi ketika EFC ini lebih sering digunakan, maka ibu menjadi kurang terampil untuk menyelesaikan problem. EFC yang efektif digunakan istri pasca melahirkan sebagai usaha penyelesaian masalah dengan melakukan pengaturan respon emosional terhadap stress.

Dari hasil analisa penggunaan coping pada istri-istri, diketahui bahwa istri sangat membutuhkan dukungan dari lingkungan terdekat. Saat istri mampu memahami adanya perasaan tidak nyaman, kemudian mencari dukungan terutama lingkungan terdekat, bisa suami atau orang tua dan lain-lain. Dukungan sosial dari lingkungan terdekat dapat meningkatkan kepercayaan diri istri untuk mampu mereduksi gejalagejala yang mengarah pada postpartum blues.

Seperti penelitian yang dilakukan oleh Hoffenar, Balen dan Hermanns (2010) pada ibu yang baru memiliki anak, bahwa tingkat stress, kecemasan, serta depresi akan menurun ketika terjalin interaksi dengan lingkungan terdekat. Pada akhirnya ibu akan mendapatkan dukungan dan pemahaman terkait masalah postpartum blues. 
Penelitian ini tidak lepas dari keterbatasan antara jumlah subjek yang sedikit dan jenis persalinan yang dialami oleh subjek. Hal ini berkaitan dengan hasil penelitian dimana dari ketiga variabel itu memperlihatkan prosentase prediksi pengaruh terbesar pada munculnya postpartum blues yaitu variabel penyesuaian diri (56.3\%), kemudian coping stress (46.1\%), dan dukungan sosial (30.2\%). Artinya selain ketiga variabel tersebut masih banyak faktor lain yang berpengaruh pada terjadinya postpartum blues, seperti faktor internal lain misalnya kepribadian, kelainan kehamilan, kondisi ibu, hormonal, dan sebagainya. Sedangkan faktor eksternal misalnya penghasilan, jenis persalinan, faktor sosial budaya, dan sebagainya.

\section{Simpulan dan Saran}

\section{Simpulan}

Berdasarkan hasil penelitian dan pembahasan yang telah dipaparkan, dapat disimpulkan bahwa coping stress, penyesuaian diri, dan dukungan sosial berhubungan dengan postpartum blues. Ketiga variabel sebagai faktor-faktor psikologis memberikan prediksi pengaruh terhadap terjadinya postpartum blues pada ibu pasca melahirkan. Variabel yang memberikan prediksi paling besar terhadap postpartum blues secara berurutan yaitu penyesuaian diri, coping stress, dan dukungan sosial.

\section{Saran}

Saran yang bisa diberikan dari hasil penelitian antara lain: bagi istri yang akan berperan menjadi ibu dan suami yang akan berperan menjadi ayah membutuhkan persiapan keilmuan untuk mengantisipasi terjadinya postpartum blues. Bagi istri yang memiliki peran baru bisa menggunakan coping yang efektif, baik PFC maupun EFC atau kolaborasi kedua jenis coping tersebut. Bagi suami dan keluarga terdekat, pemberian dukungan emosional mampu memberikan motivasi dan penyesuaian diri ibu baru. Terakhir bagi peneliti selanjutnya bisa mengembangkan hasil penelitian dengan menambah variabel-variabel psikologis yang diduga berpengaruh terhadap postpartum blues.

\section{Daftar Pustaka}

American Psychiatric Association. (2013). Diagnostic and Statistical Manual of Mental Disorders (5 $\left.5^{\text {th }} e d n\right)$, VA: Marecan Psychiatric Publishing Arlington.

Bobak, I.M., Lowdermilk, D.L., \& Jensen, M.D. (2005). Maternity Nursing: Buku Ajar Keperawatan Maternitas Edisi 4, Jakarta: EGC.

Cohen, S. \& Syme, S.L. (1985). Social Support and Health, San Francisco: Academic Press.

Cox, J.L., Holden, J.M., \& Sagovsky, R. (1987). Detection of Postnatal Depression, Developmental of the 10 Aitem Edinburh Postnatal Depression Scale, The British Journal of Psychiatry, 150(6), 782-786.

Henshaw, C. (2003). Mood Disturbance in the Early Puerperium: A Review, Archives of Womens's Mental Health, 6(2), 33-42.

Hoffenar, P.J., Balen, V.F., \& Hermanns, J. (2010). The Impact of Having a Baby on the Level a Content of Woman's Well-being, Soc India Res, 9, 279295.

Hung, Chich-Hsiu. (2004). Predictors of Postpartum Women's Health Status, Journal of Nursing Scholarship, 36(4), 345-351.

Hurlock, E.B. (1980). Psikologi Perkembangan: Suatu Pendekatan Sepanjang Kehidupan, Edisi 5, Jakarta: Erlangga.

Kail, R.V. \& Cavanaug, J.C. (2013). Human Development: A Life-span View, California: Wadsworth Cengage Learning.

McQueen, A. \& Mander, R. (2003). Tiredness and Fatigue in the Postnatal Period, Jounal of Advanced Nursing, 42(5), 463-469. 
Nes, R.B., Hauge, L.J., Landolt, M.A., Eskedal, L., Roysamb, E., Kornstad., Irgens., \& Kristensen, P. (2014). Adaptation to the Birth of a Child with Congenital Anomaly: A Prospective Longitudinal Study of Maternal Well-Being and Psychological Distress, Developmental Psychology, 50(6), 1827-1839.

Nichols, M.R., Roux, G.M., \& Harris, N.R. (2007). Primigravid and Multigravida Women: Prenatal Perspectives, The Journal of Perinatal Education, 16(2), 21-32.

Pfuhlmann, B., Stoeber, G., \& Beckmann, H. (2002). Postpartum Psychoses: Prognosis, Risk Factors, and Treatment, Curr Psychiatric, 64, 1284-1292.

Pieter, H.Z. \& Lubis, N.L. (2010). Pengantar Psikologi untuk Kebidanan, Jakarta: Kencana.

Pilliteri. (2003). Maternal and Child Health Nursing: Care of Childbearing and Childrearing Family, $3^{\text {rd }}$ edition, Lippincott.
Prawirohardjo, S. (2007). Ilmu Kebidanan, Jakarta: Yayasan Bina Pustaka.

Sarafino, E.P. (1994). Health Psychology: Biopsychosocial Interaction, Second Edition, New York: John Wiley \& Sons, Inc.

Schneiders, A.A. (1955). Personal Adjustment and Mental Health, New York: Holt, Rinehart and Winston.

Smet, B. (1994). Psikologi Kesehatan, Jakarta: Grasindo.

Sunberg, N.D., Winebager, A.A., \& Taplin, J.R. (2007). Psikologi Klinis, Edisi keempat, Yogyakarta: Pustaka Pelajar.

Supartini. (2004). Pelayanan Kesehatan bagi Ibu Hamil, Jakarta: EGC.

Sylvia, D.E. (2006). Depresi Pasca Persalinan, Jakarta: FK UI.

Thurgood, S.B.S., Avery, D.M., \& Williamson, L.M.D. (2009). Postpartum Depression (PPD), American Journal of Clinical Medicine, 6(2), 17-22.

Wikjhosastro. (2007). Ilmu Kebidanan, Jakarta: Bina Pustaka. 
Psympathic, Jurnal Ilmiah Psikologi Desember 2017, Vol. 4, No. 2, Hal : $205-218$ 